\title{
Characterization of Corrosive Bacterial Consortia Isolated from Water in a Cooling Tower
}

\author{
Rajasekar Aruliah $^{1,2}$ and Yen-Peng Ting ${ }^{1}$ \\ ${ }^{1}$ Department of Chemical \& Biomolecular Engineering, National University of Singapore, Singapore 117576 \\ ${ }^{2}$ Environmental Molecular Microbiology Lab, Department of Biotechnology, Thiruvalluvar University, Serkkadu, \\ Vellore 632 115, India
}

Correspondence should be addressed to Rajasekar Aruliah; rajasekar.aruliah@gmail.com and Yen-Peng Ting; chetyp@nus.edu.sg Received 16 October 2013; Accepted 13 November 2013; Published 4 March 2014

Academic Editors: M. Criado, W. Fürbeth, S. J. Lee, and Q. Qu

Copyright (C) 2014 R. Aruliah and Y.-P. Ting. This is an open access article distributed under the Creative Commons Attribution License, which permits unrestricted use, distribution, and reproduction in any medium, provided the original work is properly cited.

An analysis of a culturable corrosive bacterial community in water samples from a cooling tower was performed using traditional cultivation techniques and its identification based on 16S rRNA gene sequence. Seven aerobic bacterial species were identified: Pseudomonas putida ARTYP1, Pseudomonas aeruginosa ARTYP2, Massilia timonae ARTYP3, Massilia albidiflava ARTYP4, Pseudomonas mosselii ARTYP5, Massilia sp. ARTYP6, and Pseudomonas sp. ARTYP7. Although some of these species have commonly been observed and reported in biocorrosion studies, the genus Massilia is identified for the first time in water from a cooling tower. The biocorrosion behaviour of copper metal by the new species Massilia timonae ARTYP3 was selected for further investigation using a weight loss method, as well as electrochemical and surface analysis techniques (SEM, AFM, and FTIR). In contrast with an uninoculated system, thin bacterial biofilms and pitting corrosion were observed on the copper metal surface in the presence of M. timonae. The use of a biocide, bronopol, inhibited the formation of biofilm and pitting corrosion on the copper metal surface.

\section{Introduction}

In order to implement efficient monitoring and control strategies for the inhibition of biocorrosion, it is important to have knowledge of the microbial population responsible for this phenomenon, as well as interactions of different microorganisms with metallic surfaces [1-8]. In many industries, cooling towers are commonly used for heat transfer from recirculated water to the atmosphere, typically by means of trickling or spraying the water over a material with high surface area [9]. These towers generally have sizable water reservoirs, with temperature typically maintained between $25^{\circ} \mathrm{C}$ and $35^{\circ} \mathrm{C}$. These conditions provide an ideal environment for microbial growth and propagation [10-13]. Both microbes and the substrates for microbial growth can either be present in the incoming water or be introduced from the atmosphere. Copper and copper alloys, which are used in many cooling tower systems, are known to be susceptible to microbiologically influenced corrosion (MIC) $[10,14]$. Corrosion and its products have a negative impact on heat transfer and can cause a decrease in cooling efficiency of the cooling tower. Organisms responsible for MIC, including bacteria, microalgae and fungi readily attach themselves to the copper surface by excreting extracellular polymeric substances (EPS) to form a slime layer [15-18] and thereby initiate corrosion. A multilayer structure of microorganisms and their EPS have been reported to be entrapped between layers of different inorganic corrosion products on copper-based surfaces after exposure to natural seawater environment [19-24].

Interestingly, many traditional chemicals used water treatment, for example, antiscalants and zinc-based corrosion inhibitors, which are a source of nutrients that accelerate the growth of microbes in cooling towers [25]. Nonetheless, the control of corrosive bacterial fouling can be achieved through the application of effective biocides [26], or nitrate, or nitrite [27-30]. Environmental regulations and the development of water reservoirs in environmentally sensitive areas have spurred the development of easily degradable "green" 
TABLE 1: Physicochemical characteristics of water from cooling tower.

\begin{tabular}{lcc}
\hline Sl. no. & Physicochemical characteristics & Quantity \\
\hline 1 & Temperature $\left({ }^{\circ} \mathrm{C}\right)$ & 25 \\
2 & $\mathrm{pH}$ & 8.1 \\
3 & Total solids $(\mathrm{mg} / \mathrm{L})$ & 341 \\
4 & Total hardness $(\mathrm{mg} / \mathrm{L})$ & 150 \\
5 & Total alkalinity $(\mathrm{mg} / \mathrm{L})$ & 165 \\
6 & Chloride $(\mathrm{mg} / \mathrm{L})$ & 296 \\
\hline
\end{tabular}

biocides that are less toxic to higher nontarget organisms, like fish [31]. Nitrite, a specific metabolic inhibitor of corrosive bacteria, especially sulphate reducing bacteria [32, 33], is also relatively nontoxic and inexpensive and has been successfully used to inhibit corrosive bacteria [34]. 2-Bromo2-nitropropane-1,3-diol (bronopol) has a broad spectrum of antibacterial activity and is widely used as a preservative in pharmaceutical and cosmetic products and many industrial environments such as paper mills, oil exploration, and production facilities, as well as a disinfectant in cooling water $[35,36]$. The present investigation describes $16 \mathrm{~S}$ rRNA gene sequencing and the identification of bacterial communities (at the species level) present in water from a cooling tower. Microbiologically induced corrosion and the use of the biocide bronopol are also examined. As the literature on the identification of bacteria in such a system in tropical countries appears lacking, this work would be useful in the understanding of bacterial groups and biocides in cooling tower.

\section{Materials and Methods}

2.1. Sample Collection and Isolation of Bacteria. A sample of water was collected using sterilized conical flasks, from a cooling tower site located at the Faculty of Engineering at the National University of Singapore, and was transported in an ice box to the laboratory. The physiochemical parameters of the cooling water are summarized in Table 1. The water sample was serially diluted (10-fold) with sterile saline water $(0.85 \% \mathrm{w} / \mathrm{v}$ sodium chloride) and plated using pour plate technique. Winogradsky nutrient medium [37], consisting of (grams per liter): $1.0 \mathrm{~K}_{2} \mathrm{HPO}_{4}, 1.27 \mathrm{NaNO}_{3}, 0.1 \mathrm{CaCl}_{2}, 0.2$ $\mathrm{MgSO}_{4} \cdot 7 \mathrm{H}_{2} \mathrm{O}, 0.05 \mathrm{FeSO}_{4} \cdot 7 \mathrm{H}_{2} \mathrm{O}, 0.54 \mathrm{NH}_{4} \mathrm{Cl}, 1.27 \mathrm{NaNO}_{3}$, and $10 \mathrm{D}$-glucose anhydrous, was supplemented with 0.5 yeast extract and used as the medium. Viable bacteria count was enumerated on agar plates containing the supplemented Winogradsky nutrient medium (WNM) with $1.5 \%$ agar $(\mathrm{pH}$ 7). Experimental cultures were grown in conical flasks at $28 \pm 2^{\circ} \mathrm{C}$ for two days. Bacterial growth was detected by a colour change in the medium (from green to red). Total viable count of bacteria was enumerated by pour plate method using sterile WNM plates and incubated at $28 \pm 2^{\circ} \mathrm{C}$ for two days.

2.1.1. Partial Biochemical Characterization of the Isolates and Molecular Identification of Bacteria. Dissimilar aerobic bacteria isolated from the agar plates were identified according to Bergey's Manual of Determinative Bacteriology [38]. The isolated bacterial cultures were identified up to the genus level by their morphological and partial biochemical characterizations using the following: (i) gram staining, (ii) motility test, (iii) indole production, (iv) methyl red test, (v) Voges-Proskauer test, (vi) citrate utilization test, (vii) $\mathrm{H}_{2} \mathrm{~S}$ production test, (viii) carbohydrate fermentation test, (ix) catalase test, (x) oxidase test, (xi) starch, (xii) gelatin, and (xiii) lipid hydrolysis. In addition, citrate agar was used to detect any iron oxidizing activity of the isolates. Genomic DNA of the bacterial isolates was extracted according to Ausubel et al. [39]. Amplification of gene encoding small subunit ribosomal RNA was carried out using eubacterial 16S rRNA primers (forward primer $5^{\prime}$ AGAGTTTGATCCTGGCTCAG-3' (E. coli positions 8 to 27) and reverse primer $5^{\prime}$-ACGGCTACCTTGTTACGACTT-3' (E. coli positions 1494 to 1513)) [40]. Polymerase chain reaction (PCR) was performed with a $50 \mu \mathrm{L}$ reaction mixture containing $2 \mu \mathrm{L}(10 \mathrm{ng})$ of DNA as the template, with each primer at a concentration of $0.5 \mu \mathrm{M}$ and $1.5 \mathrm{mM} \mathrm{MgCl}_{2}$ and each dNTP at a concentration of $50 \mu \mathrm{M}$ as well as $1 \mu \mathrm{L}$ of Taq DNA polymerase and buffer as recommended by the manufacturer (MBI Fermentas). PCR was carried out with a Mastercycler Personal (Eppendorf) with the following program: initial denaturation at $95^{\circ} \mathrm{C}$ for $1 \mathrm{~min}, 40$ cycles of denaturation $\left(3 \mathrm{~min}\right.$ at $\left.95^{\circ} \mathrm{C}\right)$, annealing $\left(1 \mathrm{~min}\right.$ at $\left.55^{\circ} \mathrm{C}\right)$, and extension $\left(2 \mathrm{~min}\right.$ at $\left.72^{\circ} \mathrm{C}\right)$, followed by a final extension (at $72^{\circ} \mathrm{C}$ for $5 \mathrm{~min}$ ). The amplified product was purified using GFX PCR DNA and Gel Band Purification kit (Amersham Biosciences) and cloned in pTZ57R/T vector according to the manufacturer's instructions (InsT/Aclone PCR Product Cloning Kit, MBI Fermentas) and transformants were selected on LB medium containing ampicillin $(100 \mu \mathrm{g} / \mathrm{mL})$ and X-gal $(80 \mu \mathrm{g} / \mathrm{mL})$. DNA sequencing was carried out using ABI PRISM 310 Genetic Analyzer (PE Applied Biosystems). For sequencing reaction, Big Dye Ready Reaction DyeDeoxy Terminator Cycle Sequencing kit (Perkin-Elmer) was used.

2.1.2. Phylogenetic Analysis of the Bacterial Isolates. The sequences obtained were analysed with BLAST search version 2.2.20 [41] and tools of Ribosomal Database Project II Release 10 (http://rdp.cme.msu.edu) for taxonomic hierarchy of the sequences. Multiple sequence alignments were performed using CLUSTAL X2 [42] with a collection of taxonomically related sequences obtained from National Center for Biotechnology Information (NCBI) Taxonomy Homepage (http://www.ncbi.nlm.nih.gov/Taxonomy/taxonomyhome.html/) and Ribosomal Database Project-II Release 10 (http://rdp.cme.msu.edu). Phylogenetic and similitude analyses were done with the common 16S rRNA gene regions and all alignment gaps were treated as missing data. The paired similitude and pairwise distance calculations using the transversion/transition weighting $(R=s / v)$ and the Kimura-2-parameter model [43] were performed with the MEGA version 4.1 program [44]. The phylogenetic trees were constructed (neighbor-joining method) and 1000 bootstrap replications were carried out to validate internal branches [45]. MatGAT v. 2.01 software [46] was used to calculate the similitude percentages among sequences. 
2.1.3. Nucleotide Sequence Accession Numbers. The $16 \mathrm{~S}$ rRNA sequence data reported in this work has been deposited in the GenBank database, under the accession numbers from FJ755909 to FJ755915.

2.2. Biocorrosion Studies and Surface Analysis. Copper metal $(\geq 99 \% \mathrm{Cu}$ ) was used in the study of the MIC behaviour of the bacteria M. timonae ARTYP3. Different size coupons $(10 \mathrm{~mm}$ diameter disc of $2 \mathrm{~mm}$ thickness and $50 \times 10 \mathrm{~mm}$ rectangular coupons of $2 \mathrm{~mm}$ thickness) were sequentially ground with a series of grit silicon carbide papers (grades 180, 500, 800, 1200 , and 1500) to a smooth surface and finally polished to a mirror finish surface using 0.3 micron alumina powder. The polished coupons were rinsed with deionized water and surface was sterilized by immersion in an aqueous solution of $70 \%$ ethanol for one minute and finally dried in a desiccator. The prepared coupons were used for biocorrosion studies and surface analysis (using weight loss method, EIS, SEMEDX, and FTIR). The polished coupons of both shapes and sizes were introduced into a $500 \mathrm{~mL}$ conical flask containing $250 \mathrm{~mL}$ sterilized cooling tower water with $1 \%$ of WNM broth as the control system (System 1), while a sterilized cooling tower water with $1 \%$ of WNM broth inoculated with $1 \mathrm{~mL}$ of $M$. timonae bacterial culture (about $10^{5} \mathrm{CFU} / \mathrm{mL}$ ) was used as the experimental system (System 2). Another experimental system (System 3) consisted of System 2 with the addition of $5 \mathrm{ppm}$ biocide (2-bromo-2-nitropropane1, 3-diol) (bronopol). Bronopol is commonly used as a microbiocide or microbiostat for the control of slime-forming bacteria, fungi, and algae [47]. Corrosion experiments were initiated by hanging polished copper coupons on a nylon string in all the systems. After 10 days of incubation, the coupons were removed from each system for electrochemical, FTIR, and SEM-EDX analyses. Three coupons were exposed in each conical flask with duplicate flasks for each system. In total, six coupons were used for the weight loss for each system; the average weight loss and standard deviations (SD) were calculated. Impedance and potentiodynamic polarization data were obtained using an Autolab PGSTAT potentiostat. All experiments were performed in a threeelectrode electrochemical cell, with a platinum electrode as the counter electrode and an $\mathrm{Ag} / \mathrm{AgCl}$ electrode as the reference electrode. The EIS measurements (using duplicate coupons) were performed ex-situ; the coupons that were removed from the appropriate systems served as the working electrode by embedding them in a sample holder of the corrosion cell (purchased from Metrohm Pte, Ltd.). The working electrode had an exposed surface area of $0.785 \mathrm{~cm}^{2}$. $500 \mathrm{~mL}$ of the media was transferred from each system into the electrochemical cell to serve as the electrolyte for the EIS analysis [6]. EIS were made at open circuit potential using a $10 \mathrm{mV}$ amplitude sinusoidal signal over frequencies ranging from $5 \mathrm{mHz}$ to $100 \mathrm{kHz}$. Tafel plots were measured with a scan rate of $0.5 \mathrm{mVS}^{-1}$ and were obtained by scanning from the open circuit potential $\left(E_{\text {corr }}\right)$ towards $200 \mathrm{mV}$ anodically and $-200 \mathrm{mV}$ cathodically using duplicate coupons. A scanning electron microscope coupled with energy-dispersive X-ray spectroscopy analysis (SEM-EDX) microscope (JEOL, model JSM-5600) with a beam voltage of $15 \mathrm{kV}$ was used to visualize the morphology of the biofilm. Surface topography of the coupons and its elemental composition were characterized after removal of corrosion product, using SEM-EDX analyses. The corrosion product on the copper metal was removed by immersion in 50\% concentrated hydrochloric acid for 13 min (ASTM G1-90). To examine the deposition of EPS on the coupons and its chemical composition, the coupons were analysed using FTIR and SEM as described earlier [48]. An FTIR microscope (Bio-Rad Model: FTS 135) equipped with a narrow band of liquid nitrogen-cooled $\mathrm{HgCdTe}$ (MCT) detector was used for collecting the IR spectra. An atomic force microscopy (AFM) analysis was carried out to visualize the biofilm formed on the metal surface after the corrosion experiment. The coupon was removed from the media, lightly rinsed in sterile distilled water, and air-dried. The coupon was examined under an AFM (Bruker Dimension Icon Nanoscope V) in the tapping mode to capture the images of biofilms on the coupon surface. Silicon N-type cantilever nanoprobes with a spring constant of $k=25-75 \mathrm{~N} / \mathrm{m}$ (App NANO) were used.

2.3. Bacterial Adhesion to Hydrocarbons (BATH) and Salt Aggregation Test (SAT). BATH assay was used to assess the hydrophobicity of the bacteria ARTYP3, with hexadecane being used as the carbon source. Massilia timonae was harvested from growing cultures by centrifugation at $8000 \mathrm{~g}$ for $10 \mathrm{~min}$ at $4^{\circ} \mathrm{C}$, washed twice, and suspended in PBS buffer ( $\mathrm{pH} 7.1$; containing (g/L) $\mathrm{K}_{2} \mathrm{HPO}_{4}, 22.2 ; \mathrm{KH}_{2} \mathrm{PO}_{4}$, 7.26; urea, $\left.1.8 ; \mathrm{MgSO}_{4} \cdot 7 \mathrm{H}_{2} \mathrm{O}, 0.2\right)$ at an initial absorbance of $0.12-0.14$ (at $400 \mathrm{~nm}$ ). The detailed procedure for the BATH test and the calculation of the emulsifying capacity as evaluated by an emulsification index (E24) has been described earlier [2]. SAT test was used to measure the relative cell surface hydrophobicity of the bacteria. Sodium phosphate $(0.002 \mathrm{M}$, $\mathrm{pH}$ 6.8) was used to dilute a solution of $4 \mathrm{M}\left(\mathrm{NH}_{4}\right)_{2} \mathrm{SO}_{4}$ at $\mathrm{pH}$ 6.8. Serial dilutions were made giving $\left(\mathrm{NH}_{4}\right)_{2} \mathrm{SO}_{4}$ concentration ranging from 4.0 to $0.2 \mathrm{M}$ differing by $0.2 \mathrm{M}$ per dilution and ranging from 0.20 to $0.02 \mathrm{M}$ differing by $0.02 \mathrm{M}$ [49]. A bacterial suspension of $25 \mu \mathrm{L}$ in $0.002 \mathrm{M}$ sodium phosphate buffer ( $\mathrm{pH}$ 6.8) was mixed with an equal volume of salt solution into 24 -well tissue culture tray. The bacterial/salt mixture was gently rocked for $2 \mathrm{~min}$ at $25^{\circ} \mathrm{C}$ and visual observation was made against a dark background. The results were expressed as the lowest molarity of ammonium sulphate that caused bacterial aggregation.

\section{Results}

3.1. Physicochemical Characterization and Bacteriological Analysis of Cooling Tower Water. Table 1 shows the physiochemical parameters of the water sample collected from the cooling tower. The concentration of chloride and total hardness in the cooling water sample were $296 \mathrm{mg} / \mathrm{L}$ and $150 \mathrm{mg} / \mathrm{L}$, respectively. The total viable count in the supplemented WNM was $6.1 \times 10^{5} \mathrm{CFU} / \mathrm{mL}$. Preliminary identification of the bacteria by biochemical test indicated that the isolates belong to the genera Massilia sp. and Pseudomonas sp. The phenotypic profiles of the species isolated from cooling 


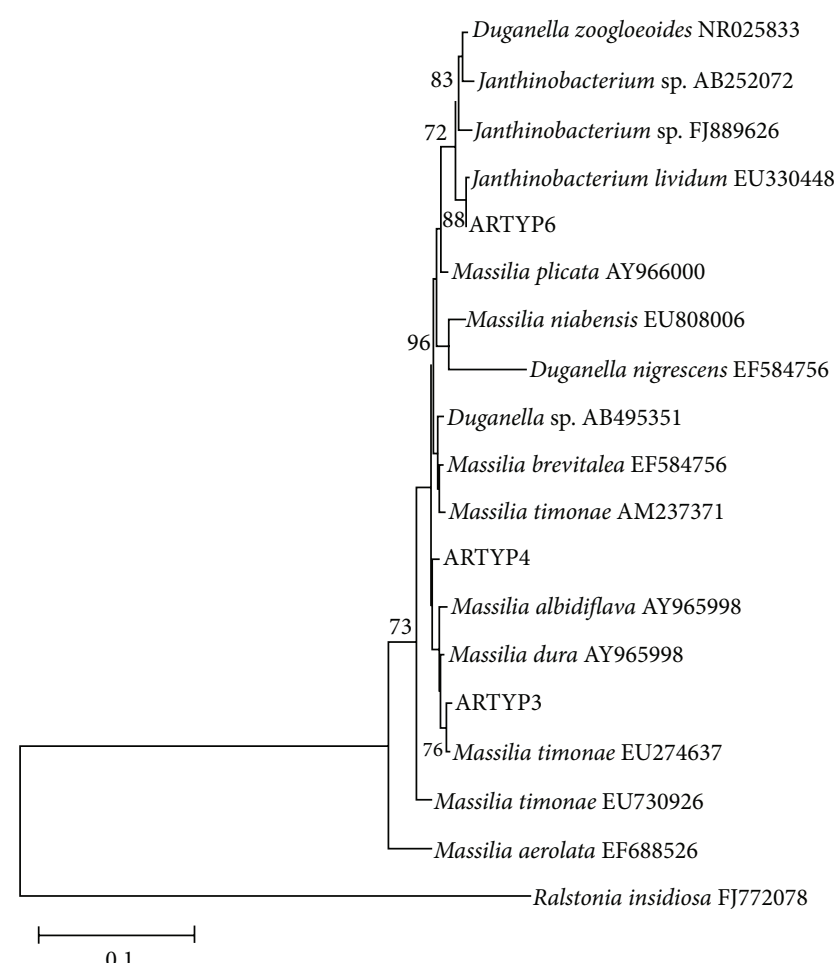

0.1

(a)

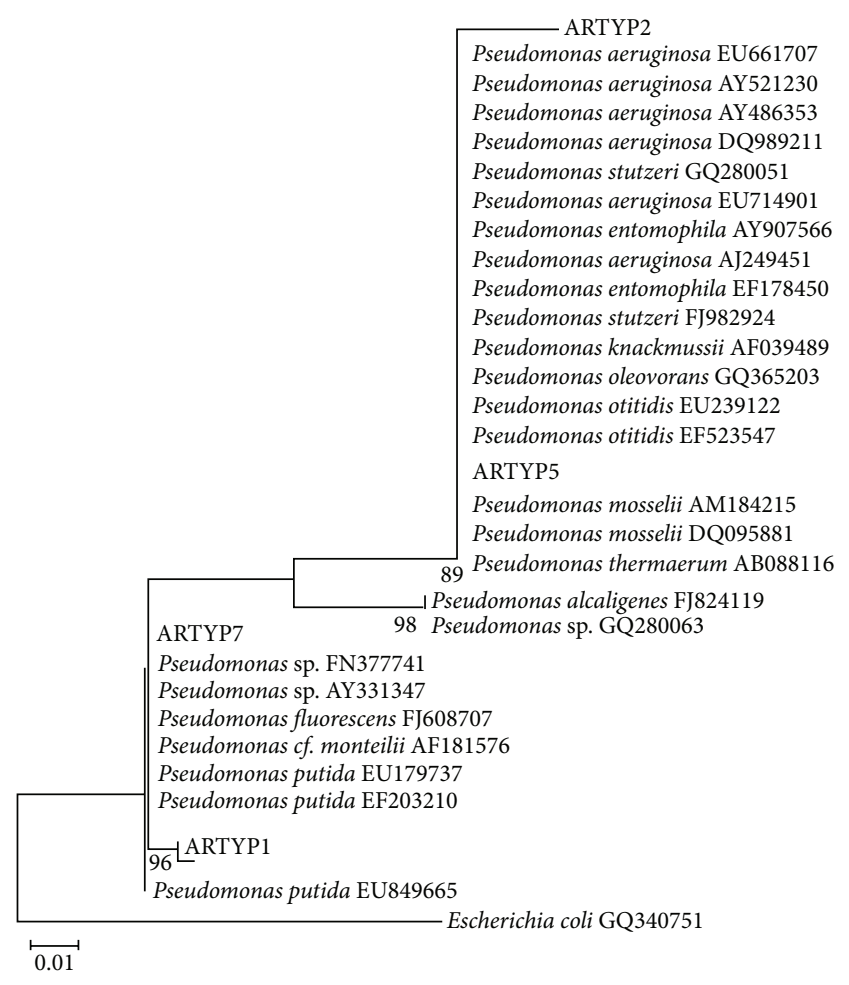

(b)

FIGURE 1: (a) Neighbor-joining tree based on 16S rRNA gene sequences, showing phylogenetic relationships between sequences of the Massilia related species. Ralstonia insidiosa was used as a bacterial out-group. Numbers at nodes indicate bootstrap values $>50 \%$ from 1,000 replicates. GenBank accession numbers are given in parentheses. The scale bar indicates sequence divergence. (b) Neighbor-joining tree based on $16 \mathrm{~S}$ rRNA gene sequences, showing phylogenetic relationships between sequences of the Pseudomonas related species. Escherichia coli was used as a bacterial out-group. Numbers at nodes indicate bootstrap values $>50 \%$ from 1,000 replicates. GenBank accession numbers are given in parentheses. The scale bar indicates sequence divergence.

water strains are shown in Tables 2(a) and 2(b). The sequences obtained were submitted to a BLAST search to retrieve the corresponding phylogenetic relatives. The phylogenetic affiliations (Gammaproteobacteria and Betaproteobacteria) were confirmed by analyses of all related species recognized by the taxonomic and classification hierarchy done with the NCBI Taxonomy Homepage and Ribosomal Database Project-II Release 10. Two neighbor-joining phylogenetic trees were constructed for the Massilia related species (Figure 1(a)) and Pseudomonas related species (Figure 1(b)), to analyse the relationships among the sequences of the ribosomal library and related organisms from the GenBank database. The similarity and species identified with the phylogenetic analysis are given in Table 3. In the Pseudomonas genera tree, all the isolates belonging to Pseudomonas genus exhibited a high nucleotide sequence similarity of more than 99\%; the corresponding bacterial isolates are, namely, Pseudomonas putida (99.2\%), Pseudomonas aeruginosa (99\%), Pseudomonas mosselii (99.5\%), and Pseudomonas sp. (98.6\%). In the class of Massilia, several isolates of the genus Massilia exhibited high sequence similarity (99\%): Massilia timonae (99.5\%) and Massilia plicata (99\%), and one isolate, Massilia albidiflava had $98.5 \%$ similarity.
Phenotypic profile of strain ARTYP3 was shown in Table 2(a). Amplification of the gene encoding for small subunit ribosomal RNA of ARTYP3 was done using eubacterial $16 \mathrm{~S}$ rDNA primers. The $16 \mathrm{~S}$ rDNA amplicons derived from ARTYP3 are cloned in $\mathrm{pTZ} 57 \mathrm{R} / \mathrm{T}$ vectors. The recombinant plasmid (pARTYP3, harboring $16 \mathrm{~S}$ rDNA insert) is partially sequenced. The sequence obtained is matched with the previously published sequences available in NCBI using BLAST. Sequence alignment and comparison revealed more than 99\% similarity with $M$. timonae. Massilia timonae ARTYP3 has been deposited in GenBank with the accession number FJ755911 and also been submitted to the German Collection of Microorganisms and Cell Cultures (DSMZ).

\subsection{Biocorrosion Studies and Surface Analysis}

3.2.1. Weight Loss Study and Electrochemical Analysis. In the control system, the average weight loss of the metal coupons $(0.0073 \mathrm{mg})$ was significantly less than in the presence of $M$. timonae ARTYP3 $(0.065 \mathrm{mg})$. The average weight loss was lowest $(0.0045 \mathrm{mg})$ in the presence of the biocide, that is, System 3. Figure 2 shows the Tafel polarization curves for copper in a cooling water system in the absence (System 1) 
TABLE 2: (a) Biochemical characterization of Massilia related species isolates from cooling tower. (b) Biochemical characterization of Pseudomonas related species isolates from cooling tower.

(a)

\begin{tabular}{|c|c|c|c|}
\hline Characteristics & FJ755911 & FJ755912 & FJ755914 \\
\hline \multicolumn{4}{|l|}{ Cell morphology } \\
\hline Gram stain & Negative & Negative & Negative \\
\hline Shape & Rod & Rod & Rod \\
\hline Motility & + & + & + \\
\hline Sporulation & - & - & - \\
\hline \multicolumn{4}{|l|}{ Growth at } \\
\hline $20^{\circ} \mathrm{C}$ & - & - & - \\
\hline $30^{\circ} \mathrm{C}$ & + & + & + \\
\hline $40^{\circ} \mathrm{C}$ & + & + & + \\
\hline \multicolumn{4}{|l|}{ Biochemical reaction } \\
\hline Indole production test & - & - & + \\
\hline Methyl red test & + & - & - \\
\hline Voges-Proskauer test & - & - & - \\
\hline Citrate utilization test & + & - & - \\
\hline Oxidase test & + & + & + \\
\hline Catalase test & + & + & + \\
\hline \multicolumn{4}{|l|}{ Production of acid from } \\
\hline Glucose & + & + & + \\
\hline Galactose & - & - & - \\
\hline Fructose & + & + & + \\
\hline Sucrose & + & + & - \\
\hline Mannitol & - & - & - \\
\hline Lactose & + & + & - \\
\hline Cellobiose & + & - & - \\
\hline Adonitol & - & - & - \\
\hline Arabinose & - & - & - \\
\hline Raffinose & - & - & - \\
\hline Inositol & - & - & - \\
\hline \multicolumn{4}{|l|}{ Hydrolysis of } \\
\hline Starch & - & + & - \\
\hline Cellulose & - & + & - \\
\hline Casein & - & + & - \\
\hline Gelatin & - & - & - \\
\hline Urea & + & - & + \\
\hline Tween 80 & - & + & - \\
\hline
\end{tabular}

(b)

\begin{tabular}{lcccc}
\hline Characteristics & FJ755909 & FJ755910 & FJ755913 & FJ755915 \\
\hline Cell morphology & & & & \\
Gram stain & Negative & Negative & Negative & Negative \\
Shape & Rod & Rod & Rod & Rod \\
Motility & + & + & - & + \\
Sporulation & - & - & - & - \\
Growth at & & & & \\
$20^{\circ} \mathrm{C}$ & + & + & + & + \\
$30^{\circ} \mathrm{C}$ & + & + & + & + \\
$40^{\circ} \mathrm{C}$ & + & + & + & + \\
\hline
\end{tabular}

(b) Continued.

\begin{tabular}{|c|c|c|c|c|}
\hline Characteristics & FJ755909 & FJ755910 & FJ755913 & FJ755915 \\
\hline \multicolumn{5}{|l|}{ Biochemical reaction } \\
\hline Indole production test & - & + & + & + \\
\hline Methyl red test & + & - & + & + \\
\hline Voges-Proskauer test & - & - & - & - \\
\hline Citrate utilization test & + & - & - & - \\
\hline Oxidase test & + & - & - & - \\
\hline Catalase test & + & + & + & + \\
\hline \multicolumn{5}{|l|}{ Production of acid from } \\
\hline Glucose & + & + & + & + \\
\hline Galactose & - & - & - & - \\
\hline Fructose & + & + & + & + \\
\hline Sucrose & - & + & + & + \\
\hline Mannitol & - & - & - & - \\
\hline Lactose & + & - & - & - \\
\hline Cellobiose & + & - & - & - \\
\hline Adonitol & - & - & - & - \\
\hline Arabinose & + & + & + & + \\
\hline Raffinose & - & - & - & - \\
\hline Inositol & - & - & - & - \\
\hline \multicolumn{5}{|l|}{ Hydrolysis of } \\
\hline Starch & + & + & + & + \\
\hline Cellulose & - & + & + & + \\
\hline Casein & - & + & + & + \\
\hline Gelatin & + & - & - & - \\
\hline Urea & - & + & + & + \\
\hline Tween 80 & - & + & + & + \\
\hline
\end{tabular}

and in the presence (System 2) of ARTYP3 and in the biocide system (System 3). The corresponding electrochemical data are presented in Table 4. The corrosion currents for System 1 and System 2 were $3.9 \times 10^{-9} \mathrm{~A} / \mathrm{cm}^{2}$ and $5.5 \times 10^{-7} \mathrm{~A} / \mathrm{cm}^{2}$, respectively, while, in presence of the biocide (System 3 ), the current was $1 \times 10^{-9} \mathrm{~A} / \mathrm{cm}^{2}$. The open circuit potential (OCP) for the control system and in the presence of ARTYP3 and in the biocide systems were $-255 \mathrm{mV},-225 \mathrm{mV}$, and $-275 \mathrm{mV}$, respectively. Nyquist plots for the control and inoculated systems are given in Figures 3(a) and 3(b). The solution resistance $\left(R_{s}\right)$ and the charge transfer resistance $\left(R_{\mathrm{ct}}\right)$ were derived from impedance measurements. In the control and in the presence of ARTYP3, the charge transfer resistance $R_{\mathrm{ct}}$ values were $12.7 \Omega \cdot \mathrm{cm}^{2}$ and $0.01 \Omega \cdot \mathrm{cm}^{2}$, respectively; $R_{\mathrm{ct}}$ increased significantly to $163 \Omega \cdot \mathrm{cm}^{2}$ in the presence of the biocide (Table 4).

3.2.2. Surface Analysis. Biofilm formed on the copper metal surface in System 2 and System 3 was observed under SEM and is presented in Figure 4. ARTYP3 colonized the metal surface and formed a thick biofilm (Figure 4(a)) while significantly less biofilm was formed when the biocide was present (Figure 4(b)). The cell density of ARTYP3 at the end of the biocorrosion study was about $2.3 \times 10^{7} \mathrm{CFU} / \mathrm{mL}$ and $1.2 \times 10^{2} \mathrm{CFU} / \mathrm{mL}$ in the absence and presence of 
TABLE 3: 16S rRNA sequence analysis of the bacterial isolates.

\begin{tabular}{lcccc}
\hline Name of the isolates & Taxonomic phylum & Closest relationship in GenBank & Similarity (\%) & Microbial group identified \\
\hline ARTYP1 & & Pseudomonas putida (EU849665) & 99.2 & Pseudomonas putida (FJ755909) \\
ARTYP2 & Gammaproteobacteria & Pseudomonas aeruginosa (EU661707) & 99.0 & Pseudomonas aeruginosa (FJ755910) \\
ARTYP5 & Pseudomonas mosselii (AM184215) & 99.5 & Pseudomonas mosselii (FJ755913) \\
ARTYP7 & Pseudomonas sp. (FN377741) & 98.6 & Pseudomonas sp. (FJ755915) \\
\hline ARTYP3 & Massilia timonae (EU274637) & 99.5 & Massilia timonae (FJ755911) \\
ARTYP4 & Betaproteobacteria & Massilia albidiflava (AY965999) & 98.5 & Massilia albidiflava (FJ755912) \\
ARTYP6 & & Massilia plicata (AY966000) & 99.0 & Massilia plicata (FJ755914) \\
\hline
\end{tabular}

TABLE 4: Polarization and impedance parameters for copper in the presence/absence of bacterial isolates and biocide.

\begin{tabular}{lcccccc}
\hline Systems & & Polarization & \multicolumn{3}{c}{ Impedance data } \\
& $E_{\text {corr }}(\mathrm{mV})$ & $i_{\text {corr }}\left(\mathrm{A} / \mathrm{cm}^{2}\right)$ & Corrosion rate $(\mathrm{mm} / \mathrm{y})$ & $R_{s} \Omega$ & $R_{\mathrm{ct}} \Omega$ & $R_{p} \Omega$ \\
\hline System 1 & -255 & $3.9 \times 10^{-9}$ & $4.5 \times 10^{-5}$ & 100 & 12.7 \\
System 2 & -225 & $5.5 \times 10^{-7}$ & $6.5 \times 10^{-3}$ & 148 & 0.01 \\
System 3 & -275 & $1 \times 10^{-9}$ & $1.1 \times 10^{-5}$ & 181 & $1.4 \times 10^{3}$ \\
\hline
\end{tabular}

System 1: $250 \mathrm{~mL}$ sterilized cooling tower water with $1 \%$ of supplemented WNM medium. System 2: System 1 with $1 \mathrm{~mL}$ of $M$. timonae bacterial culture (about $10^{5} \mathrm{CFU} / \mathrm{mL}$ ). System 3: Systems 1 and 2 with the addition of 5 ppm biocide (2-bromo-2-nitropropane-1, 3-diol) (bronopol).

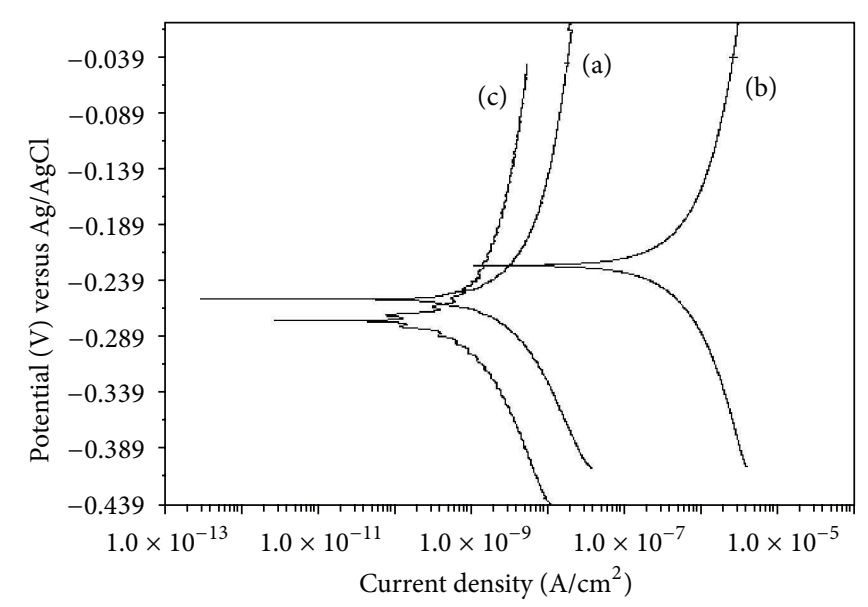

FIgURE 2: Tafel polarization curves of copper metal coupon in various systems after 10 -day immersion in cooling water at $28^{\circ} \mathrm{C}$ : (a) control, (b) M. timonae ARTYP3, and (c) M. timonae ARTYP3 inoculated with biocide.

the biocide. AFM images (two- and three-dimensional view) of the ARTYP3 biofilm after exposure to the supplemented WNM medium are shown in Figure 4(c) where the thick biofilm on the copper metal surface is evident (Figure 4(c)). Figure 5 shows the SEM topography of the copper coupons after 10 days of exposure in the uninoculated system (Figure 5(a)), in the presence of the isolate (Figure 5(b)), and in the system with the isolate and the biocide (Figure 5(c)), after the removal of corrosion products and biofilm. Pitting corrosion was evident on the surface of the copper metal in the bacteria inoculated system but, in presence of the biocide, significantly less corrosion was observed. FTIR spectra of the ARTYP3 biofilm on the copper metal coupons exposed to the media with and without bronopol are shown in
Figure 6. The distinct narrow peaks $\left(1140 \mathrm{~cm}^{-1}\right)$ observed in the spectrum (Figure 6(a)) may be ascribed to the C$\mathrm{O}-\mathrm{C}$ group of polysaccharides. A broad band was noted in the range of $3000-3500 \mathrm{~cm}^{-1}$, which may be assigned to adsorbed water molecule $\mathrm{OH} / \mathrm{NH}$ group. The protein amide I $(\mathrm{C}=\mathrm{O}$ stretch weakly coupled with $\mathrm{C}-\mathrm{N}$ stretch and $\mathrm{N}-\mathrm{H}$ bending) and amide II (C-N stretch strongly coupled with $\mathrm{N}-$ $\mathrm{H}$ bending) regions are found at approximately $1650 \mathrm{~cm}^{-1}$ and $1550 \mathrm{~cm}^{-1}$, respectively. The covalent property of the C-O$\mathrm{Cu}$ bond results in a strong band due to the $\mathrm{C}-\mathrm{O}-\mathrm{C}$ stretching vibration for ester in the range of $1675-1620 \mathrm{~cm}^{-1}$. This region reflects vibrational modes of carbohydrate $\mathrm{C}-\mathrm{O}-\mathrm{C}$ and the broad phosphate-oxygen stretch. The band at $1242-1254 \mathrm{~cm}^{-1}$ is due to the $-\mathrm{OH}$ group. In the presence of bronopol, no significant peaks were observed on the copper metal surface in the FTIR spectrum (Figure 6(b)).

The bacteria cell surface hydrophobicity was assessed using BATH and SAT assays. Grown in $n$-hexadecane containing medium, ARTYP3 was found to be hydrophobic. The emulsifying capacity of ARTYP3 evaluated using the emulsification index $(E)$ at different time periods, 24, 48, and $72 \mathrm{~h}$, was about $E_{24} 18 \%, E_{48} 22 \%$, and $E_{72} 22 \%$ [50]. Aggregation of $M$. timonae ARTYP3 with $\left(\mathrm{NH}_{4}\right)_{2} \mathrm{SO}_{4}$ was noted visually (against a dark background) even at the lowest calt concentration $(0.002 \mathrm{M})$. This observation confirms the hydrophobic nature of the cell surface.

\section{Discussion}

As reported by Gallego et al. [51] Massilia timonae is one of five species under the genus Massilia belonging to the family of Oxalobacteraceae (Betaproteobacteria). Subsequently, other species of the genus Massilia were also successfully isolated from blood and environmental samples [52, 53]. M. timonae is identified and reported for the first time in water 
from a cooling tower. The bacteria $M$. timonae are Gramnegative, motile, and rod-shaped. Catalase and oxidase were present in all the Massilia sp. strains (Table 2(a)). The isolates ARTYP1-ARTYP7 from the cooling water deposited ferric hydroxide precipitate around the colony and formed as rustred colour. As shown in the Massilia genera phylogenetic tree (Figure 1(a)), the isolates exhibited high sequence similarity with $M$. timonae, M. albidiflava, and M. plicata (>98.5\%). The involvement of $M$. timonae is unexpected as this species has not previously been reported to be associated with MIC in cooling tower systems.

Pseudomonas species, the most prevalent in industrial water and seawater, have been reported in the corrosion of mild steel, stainless steel, and aluminum alloys in marine and industrial habitats $[54,55]$. Aerobic Pseudomonas species are recognized to be the pioneer colonizer in biofilm formation; their primary role appears to be to create an oxygen-free environment to harbor other corrosive bacteria (such as the sulphate reducing bacteria). It has been reported that these aerobic slime-formers often grow in a patchy distribution over the metal surface and exclude oxygen via respiration, thereby creating oxygen concentration cells or ion concentration cells [56]. Pseudomonas has also been shown to enhance the corrosion of metals and cause pitting corrosion on the metal surface. Pedersen et al. [56] reported that Pseudomonas sp. facilitated the breakdown of passivity by excreting organic acids, thus resulting in an increase in the corrosion rates of metals. Busalmen et al. [57] attributed the acceleration in the corrosion rate to the cathodic reduction by the catalase secreted by Pseudomonas. The Pseudomonas species isolated from the cooling tower also produce the catalase enzyme. In the Pseudomonas phylogenetic tree, the isolates exhibited a high nucleotide sequence similarity with P. aeruginosa, P. mosselii, P. putida, and Pseudomonas sp. with high similarity values (>98\%). The phylogenetic analysis of the isolates showed the dominance of Pseudomonas sp. among Gammaproteobacteria, and Massilia sp. among Betaproteobacteria (Table 3 ).

The effect of the bacteria on the metal surface and its induced corrosion process is manifested through electrochemical analysis. The data obtained from the polarization study in the presence/absence of ARTY3 and the biocide are presented in Table 4. The open circuit potential (OCP) in the presence of the biocide was negative $(-275 \mathrm{mV})$ when compared to control $(-225 \mathrm{mV})$, thus indicating that the biocide bronopol acts as a mixed inhibitor and suppresses both anodic and cathodic current significantly. The corrosion rate was higher in the presence of ARTYP3 $\left(6.5 \times 10^{-3} \mathrm{~mm} / \mathrm{y}\right)$, when compared to the control $\left(4.5 \times 10^{-5} \mathrm{~mm} / \mathrm{y}\right)$. In the presence of the biocide, however, the corrosion rate and current density were reduced (to about $1.1 \times 10^{-5} \mathrm{~mm} / \mathrm{y}$ and $\left.1 \times 10^{-9} \mathrm{~A} / \mathrm{cm}^{2}\right)$. In the presence of ARTYP3, the corrosion current was the highest, thus indicating that ARTYP3 accelerates the corrosion of copper. Figure 2(b) shows that, in the presence of ARTYP3, both the anodic and cathodic curves shifted to the right when compared to the control, which indicated enhanced (anodic and cathodic) reactions, with the uptake of hydrogen and dissolution of copper on

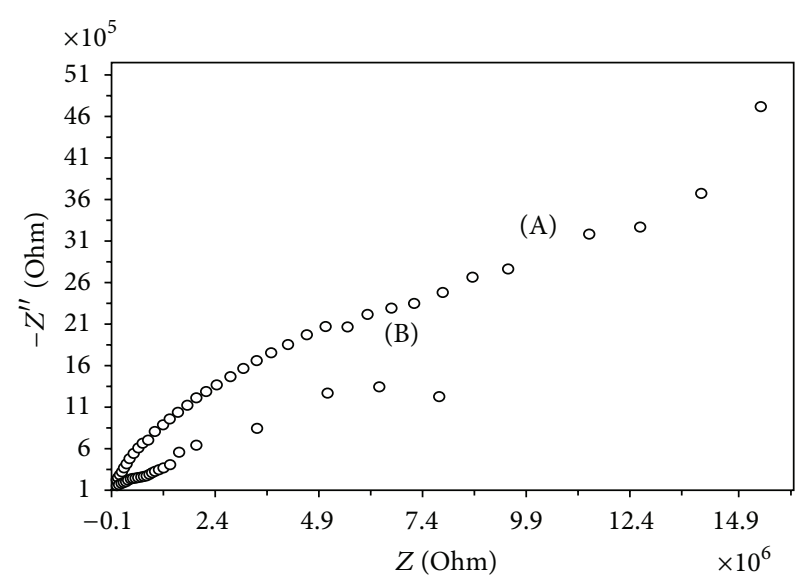

(a)

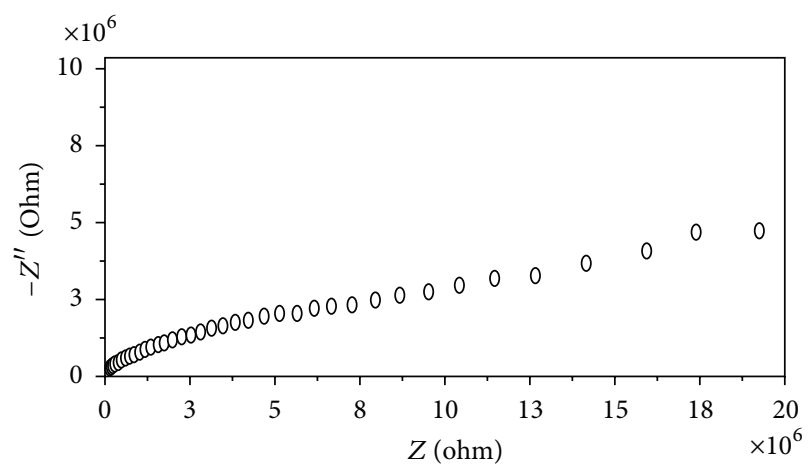

(b)

FIGURE 3: (a) Impedance curves of copper metal coupon in various systems after 10 -day immersion in cooling water at $28^{\circ} \mathrm{C}$ : (A) control system and (B) M. timonae ARTYP3. (b) Impedance curves of copper metal coupon in $M$. timonae ARTYP3 inoculated with biocide after 10-day immersion in cooling water at $28^{\circ} \mathrm{C}$.

the metal surface. This led to pitting corrosion [58]. However, in the presence of the biocide (System 3), both anodic and cathodic reactions were suppressed significantly (i.e., Figure 2(c)). The suppression of corrosion current was due to the inhibition of the biofilm formation on the copper surface. Compared to the control, the resistances of the solution, $R_{s}$, in the bacterial cultures were higher, possibly due to bacterial exopolysaccharides in the medium. In the presence of the biocide (System 3), the charge transfer resistance, $R_{\mathrm{ct}}$, was significantly higher $(163 \Omega)$ when compared to the control $(12.7 \Omega)$ and System $2(0.01 \Omega)$, possibly due to the compact nitrogen band with copper oxide layer on the metal surface which inhibits biocorrosion. In the presence of ARTYP3, the impedance curve (Figure 3 ) shows an activation control process due to defects and pores in the adsorbed film on the metal surface [59]. However, in the presence of the biocide, the curve shows a large and well-defined semicircle capacitive loop (Figure 3(b)). The capacitive loop shows the formation of the intact part of the adsorbed film on the metal surface and is large compared to the control. This observation corroborates the polarization studies. 


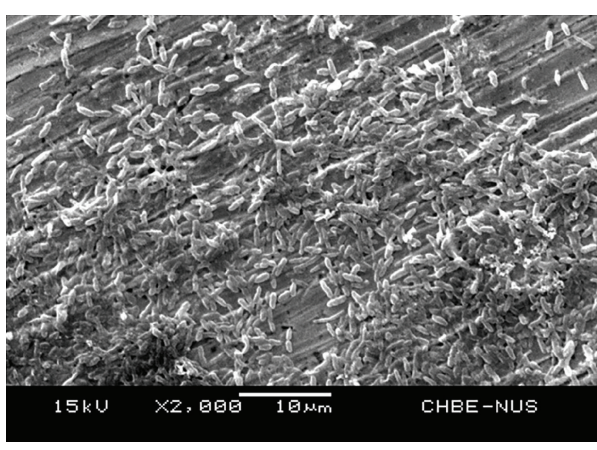

(a)

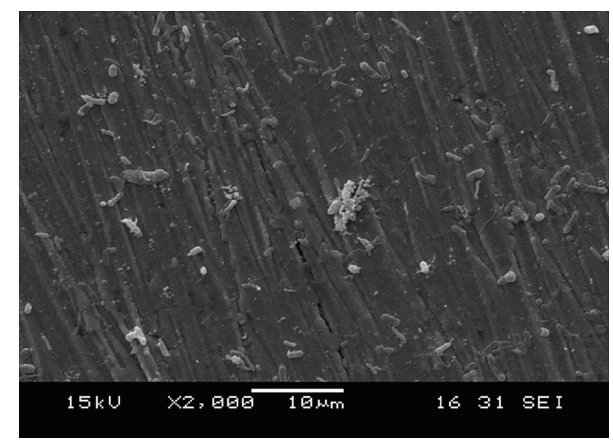

(b)

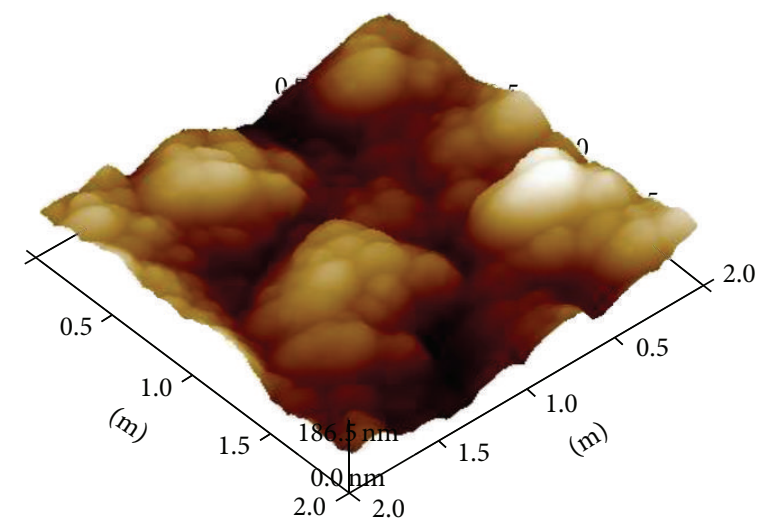

(c)

FIGURE 4: SEM and AFM micrographs of the copper surface coupon after immersion in cooling water systems (a) SEM: M. timonae ARTYP3 and (b) SEM: M. timonae ARTYP3 inoculated with biocide (c) AFM (three-dimensional view) M. timonae biofilm.

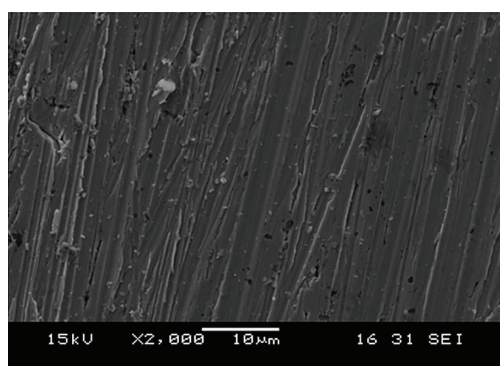

(a)

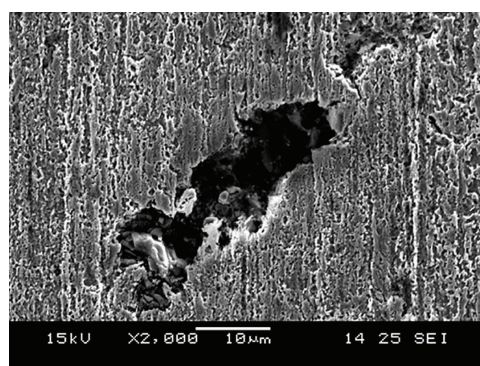

(b)

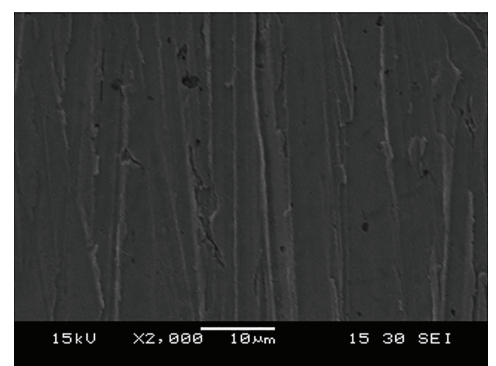

(c)

FIGURE 5: SEM micrograph of the copper surface coupon after immersion in cooling water systems (a). Copper surface exposed to the medium without bacteria and biocide. (b) Copper surface exposed to M. Timonae. (c) Copper surface exposed to M. timonae with the biocide bronopol.

Weight loss and corrosion rate were also monitored in the presence or absence of M. timonae and the biocide. Weight loss increased in the presence of the ARTYP3 $(0.065 \mathrm{mg})$ compared to the uninoculated system $(0.0073 \mathrm{mg})$ but was significantly reduced to about $0.0045 \mathrm{mg}$ in the presence of the biocide. The corrosion rate, at $0.0177,0.1573$, and $0.0109 \mathrm{~mm} /$ year in Systems 1, 2, and 3, respectively, showed that bronopol inhibits the pitting corrosion of copper metal. Unlike the control system where uniform corrosion was noted, severe pitting attacks were observed over the surface of steel in the presence of ARTYP (Figure 5). In the presence of the biocide (System 3), no obvious corrosion pit was observed (Figure 5), thus showing that the biocide significantly inhibits biofilm formation (Figure 4) by ARTYP3 on the metal surface and minimizes corrosion. M. timonae and Pseudomonas sp. contribute to biofilm formation by producing exopolysaccharides and facilitating the attachment of other microorganisms, hence accelerating the corrosion process [60]. Massilia sp. and Pseudomonas sp. are capable of oxidizing copper ions as electron donors and gaining energy from the oxidation of 


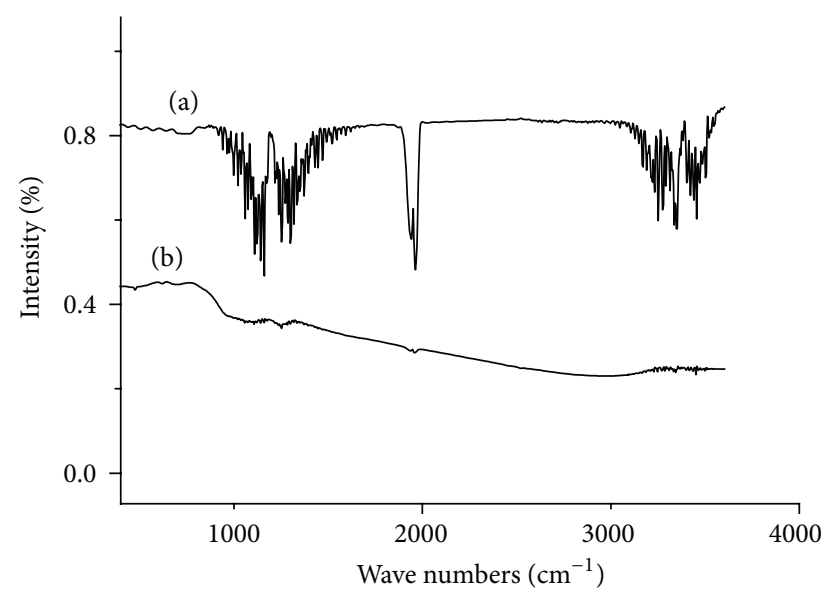

FIGURE 6: FTIR spectrum of copper surface coupon after immersion of cooling water systems. (a) M. timonae ARTYP3 and (b) $M$. timonae ARTYP3 inoculated with biocide.

copper to copper oxides. The bacteria promote the formation of copper oxides at low pH (5.0) which leads to pitting corrosion.

Surface hydrophobicity of microorganisms is recognized as a dominant factor that influences its adhesion on surfaces and hence surface corrosion. In biological systems, hydrophobic interactions are usually the strongest of all longrange noncovalent interactions and can be defined as the attraction between apolar or slightly polar molecules, particles, or cells, when immersed in water [61]. The hydrophobic nature of ARTYP3 has been established, and the emulsification index $(E)$ was found to increase with the time of exposure [50]. This suggests the production of biosurfactant (rhamnolipid) by ARTYP3 and thus leads to higher uptake of hexadecane as the carbon source. In addition, aggregates of ARTYP3 were formed, even at the lowest dilution of ammonium sulphate, due to the hydrophobic nature of the cells. A higher hydrophobic behavior of the bacterial isolate induces greater adhesion on the metal surface $[50,62]$.

EPS comprises macromolecules such as proteins, polysaccharides, nucleic acids, and phospholipids. The capacity of EPS to bind metal ions is an important factor in determining the MIC behavior of the bacterial isolates [48, 60,63]. Figure 4(a) shows typical rod-shaped cells (about $1 \mu \mathrm{m}$ ) on the metal surface (Figure 4(a)). In the presence of the biocide, significantly less bacteria were observed (Figure 4(b)). A thick layer of biofilm with clusters of microbial cells and EPS was also noted on the metal surface (Figure 4(c)). FTIR (Figure 6(b)) confirms the adhesion of EPS $\left(\mathrm{COO}^{-}\right.$, amide groups) secreted by the bacteria on the metal surface [63]. The addition of bronopol resulted in significant reduction in all the peak intensity, due to the inhibition of biofilm formation. The antibacterial mechanism of bronopol has been attributed to its interaction with essential thiols within the cell [32, 33]. Shepherd et al. [36] have also reported that bronopol catalyses the oxidation of thiol groups to disulfides with the consumption of oxygen. Such catalytic reaction also results in the generation of free radicals which subsequently inhibits the growth of the bacteria.

\section{Conclusion}

In this study, a corrosive bacterial community in water samples collected from a cooling tower was cultivated using traditional cultivation techniques and identified using $16 \mathrm{~S}$ rRNA gene sequence. $M$. timonae was found to be the dominant corrosive bacteria amongst the culturable organisms and accelerated severe pitting corrosion in copper metal. The genus Massilia is identified for the first time in water from a cooling tower. The biosurfactant produced by the ARTYP3 contributes to an increase in the cell surface hydrophobicity of the bacteria and enhanced the bacterial adhesion on the copper metal surface. SEM-EDAX, AFM, and FTIR analyses of the copper metal coupons with bacterial biofilm developed after exposure to cooling water confirmed that EPS accumulate with exposure time and revealed that biofilms were formed as microcolonies, which subsequently caused pitting corrosion. Bronopol was shown to be an effective biocide in inhibiting both biofilm formation on the copper metal surface and the subsequent biocorrosion.

\section{Conflict of Interests}

The authors declare that there is no conflict of interests.

\section{Acknowledgments}

Rajasekar Aruliah acknowledges the award of a Research Fellowship supported under a Research Grant (R- 279000-227-112) from the National University of Singapore, Singapore. Rajasekar Aruliah is thankful to the Department of Biotechnology (Government of India) for continuing his research career in India through the Ramalingaswami Fellow Award 2013.

\section{References}

[1] C.-G. Peng, J. K. Park, and R. W. Patenaude, "Statistics-based classification of microbially influenced corrosion in freshwater systems," Water Research, vol. 28, no. 4, pp. 951-959, 1994.

[2] A. Rajasekar and Y.-P. Ting, "Microbial corrosion of aluminum 2024 aeronautical alloy by hydrocarbon degrading bacteria Bacillus cereus ACE4 and Serratia marcescens ACE2," Industrial \& Engineering Chemistry Research, vol. 49, no. 13, pp. 60546061, 2010.

[3] H. A. Videla, "Prevention and control of biocorrosion," International Biodeterioration \& Biodegradation, vol. 49, no. 4, pp. 259-270, 2002.

[4] A. Rajasekar, S. Maruthamuthu, N. Palaniswamy, and A. Rajendran, "Biodegradation of corrosion inhibitors and their influence on petroleum product pipeline," Microbiological Research, vol. 162, no. 4, pp. 355-368, 2007.

[5] A. Rajasekar, T. G. Babu, S. K. Pandian, S. Maruthamuthu, N. Palaniswamy, and A. Rajendran, "Biodegradation and corrosion behavior of manganese oxidizer Bacillus cereus ACE4 in 
diesel transporting pipeline," Corrosion Science, vol. 49, no. 6 , pp. 2694-2710, 2007.

[6] A. Rajasekar, B. Anandkumar, S. Maruthamuthu, Y.-P. Ting, and P. K. S. M. Rahman, "Characterization of corrosive bacterial consortia isolated from petroleum-product-transporting pipelines," Applied Microbiology and Biotechnology, vol. 85, no. 4, pp. 1175-1188, 2010.

[7] A. Rajasekar and Y.-P. Ting, "Role of inorganic and organic medium in the corrosion behavior of Bacillus megaterium and Pseudomonas sp. in stainless steel SS 304," Industrial \& Engineering Chemistry Research, vol. 50, no. 22, pp. 12534-12541, 2011.

[8] J. Elguindi, S. Moffitt, H. Hasman, C. Andrade, S. Raghavan, and C. Rensing, "Metallic copper corrosion rates, moisture content, and growth medium influence survival of copper ion-resistant bacteria," Applied Microbiology and Biotechnology, vol. 89, no. 6, pp. 1963-1970, 2011.

[9] R. MacDonald and V. S. Brözel, "Community analysis of bacterial biofilms in a simulated recirculating cooling-water system by fluorescent in situ hybridization with rRNA-targeted oligonucleotide probes," Water Research, vol. 34, no. 9, pp. 24392446, 2000 .

[10] P. J. Bremer and G. G. Geesey, "Laboratory-based model of microbiologically induced corrosion of copper," Applied and Environmental Microbiology, vol. 57, no. 7, pp. 1956-1962, 1991.

[11] S. W. Borenstein, Microbiologically Influenced Corrosion Handbook, Woodhead, Cambridge, UK, 1994.

[12] J. M. Kusnetsovi, P. J. Martikainen, H. R. Jousimies-Somer et al., "Physical, chemical and microbiological water characteristics associated with the occurrence of Legionella in cooling tower systems," Water Research, vol. 27, no. 1, pp. 85-90, 1993.

[13] H. Yamamoto, M. Sugiura, S. Kusunoki, T. Ezaki, M. Ikedo, and E. Yabuuchi, "Factors stimulating propagation of Legionella in cooling tower water," Applied and Environmental Microbiology, vol. 58, no. 4, pp. 1394-1397, 1992.

[14] P. Wagner and B. Little, "Impact of alloying on microbiologically influenced corrosion-a review," Materials Performance, vol. 32, no. 9, pp. 65-68, 1993.

[15] G. G. Geesey and P. J. Bremer, "Evaluation of copper corrosion under bacterial biofilms," in Proceedings of the Annual Meeting National Association of Corrosion Engineers, paper 111, NACE, Cincinnati, Ohio, USA, 1991.

[16] H.-Y. Cheung, G. K.-L. Chan, S.-H. Cheung, S.-Q. Sun, and W.F. Fong, "Morphological and chemical changes in the attached cells of Pseudomonas aeruginosa as primary biofilms develop on aluminium and $\mathrm{CaF}_{2}$ plates," Journal of Applied Microbiology, vol. 102, no. 3, pp. 701-710, 2007.

[17] P. Angell and A. H. L. Chamberlain, "The role of extracellular products in copper colonisation," International Biodeterioration, vol. 27, no. 2, pp. 135-143, 1991.

[18] J. Li, J. Li, W. Yuan, and Y. Du, "Biocorrosion characteristics of the copper alloys BFe30-1-1 and HSn70-1AB by SRB using Atomic Force Microscopy and Scanning Electron Microscopy," International Biodeterioration \& Biodegradation, vol. 64, no. 5, pp. 363-370, 2010.

[19] M. W. Mittelman and G. G. Geesey, "Copper-binding characteristics of exopolymers from a freshwater-sediment bacterium," Applied and Environmental Microbiology, vol. 49, no. 4, pp. 846851, 1985.

[20] I. B. Beech and J. Sunner, "Biocorrosion: towards understanding interactions between biofilms and metals," Current Opinion in Biotechnology, vol. 15, no. 3, pp. 181-186, 2004.
[21] G. Blunn, "Biological fouling of copper and copper alloys," in Biodeterioration, S. Barry, D. R. Hozughton, G. C. Llewellyn, and C. E. O'Rear, Eds., vol. 6, pp. 567-575, CAB International, Slough, UK, 1986.

[22] N. Ceyhan and G. Ozdemir, "Extracellular polysaccharides produced by cooling water tower biofilm bacteria and their possible degradation," Biofouling, vol. 24, no. 2, pp. 129-135, 2008.

[23] G. D. Drysdale, H. C. Kasan, and F. Bux, "Denitrification by heterotrophic bacteria during activated sludge treatment," Water SA, vol. 25, no. 3, pp. 357-362, 1999.

[24] G. T. Huang, K.-Y. Chan, and H. H. P. Fang, "Microbiologically induced corrosion of $70 \mathrm{Cu}-30 \mathrm{Ni}$ alloy in anaerobic seawater," Journal of the Electrochemical Society, vol. 151, no. 7, pp. B434B439, 2004.

[25] J. M. Kusnetsov, A. I. Tulkki, H. E. Ahonen, and P. J. Martikainen, "Efficacy of three prevention strategies against legionella in cooling water systems," Journal of Applied Microbiology, vol. 82, no. 6, pp. 763-768, 1997.

[26] S. Okabe, W. L. Jones, W. Lee, and W. G. Characklis, "Anaerobic SRB biofilms in industrial water systems: a process analysis," in Biofouling and Biocorrosion in Industrial Water Systems, G. G. Geesy, Z. Lewandowsky, and H. C. Flemming, Eds., pp. 189-204, Lewis, Boca Raton, Fla, USA, 1994.

[27] C. U. Schwermer, G. Lavik, R. M. Abed et al., "Impact of nitrate on the structure and function of bacterial biofilm communities in pipelines used for injection of seawater into oil fields," Applied and Environmental Microbiology, vol. 74, no. 9, pp. 2841-2851, 2008.

[28] J. Wen, K. Zhao, T. Gu, and I. I. Raad, "A green biocide enhancer for the treatment of sulfate-reducing bacteria (SRB) biofilms on carbon steel surfaces using glutaraldehyde," International Biodeterioration \& Biodegradation, vol. 63, no. 8, pp. 1102-1106, 2009.

[29] S. A. Haveman, E. A. Greene, C. P. Stilwell, J. K. Voordouw, and G. Voordouw, "Physiological and gene expression analysis of inhibition of Desulfovibrio vulgaris Hildenborough by nitrite," Journal of Bacteriology, vol. 186, no. 23, pp. 7944-7950, 2004.

[30] R. Zuo, D. Örnek, B. C. Syrett et al., "Inhibiting mild steel corrosion from sulfate-reducing bacteria using antimicrobialproducing biofilms in Three-Mile-Island process water," Applied Microbiology and Biotechnology, vol. 64, no. 2, pp. 275-283, 2004.

[31] R. Frey, "Award-winning biocides are lean, mean, and green," Today's Chemist at Work, vol. 7, no. 6, pp. 34-35, 37-38, 1998.

[32] E. A. Greene, C. Hubert, M. Nemati, G. E. Jenneman, and G. Voordouw, "Nitrite reductase activity of sulphate-reducing bacteria prevents their inhibition by nitrate-reducing, sulphideoxidizing bacteria," Environmental Microbiology, vol. 5, no. 7, pp. 607-617, 2003.

[33] E. A. Greene, V. Brunelle, G. E. Jenneman, and G. Voordouw, "Synergistic inhibition of microbial sulfide production by combinations of the metabolic inhibitor nitrite and biocides," Applied and Environmental Microbiology, vol. 72, no. 12, pp. 7897-7901, 2006.

[34] A. J. Telang, S. Ebert, J. M. Foght et al., "Effect of nitrate injection on the microbial community in an oil field as monitored by reverse sample genomeprobing," Applied and Environmental Microbiology, vol. 63, no. 5, pp. 1785-1793, 1997. 
[35] B. Croshaw, M. J. Groves, and B. Lessel, "Some properties of bronopol, a new antimicrobial agent active against Pseudomonas aeruginosa," The Journal of Pharmacy and Pharmacology, vol. 16, no. S1, pp. 127T-130T, 1964.

[36] J. A. Shepherd, R. D. Waigh, and P. Gilbert, "Antibacterial action of 2-bromo-2-nitropropane-1,3-diol (bronopol)," Antimicrobial Agents and Chemotherapy, vol. 32, no. 11, pp. 1693-1698, 1988.

[37] D. Starosvetsky, R. Armon, J. Yahalom, and J. Starosvetsky, "Pitting corrosion of carbon steel caused by iron bacteria," International Biodeterioration \& Biodegradation, vol. 47, no. 2, pp. 7987, 2001.

[38] J. G. Holt, N. R. Kreig, P. H. A. Sneath, J. T. Stanely, and S. T. Williams, Eds., Bergey's Manual of Determinative Bacteriology, Williams \& Wilkins, Baltimore, Md, USA, 1994.

[39] F. M. Ausubel, R. Brent, R. E. Kingston, D. D. Moore, J. G. Seidelman, and K. E. Struhl, Current Protocols in Molecular Biology, vol. 2, John Wiley \& Sons, New York, NY, USA, 1988.

[40] W. G. Weisburg, S. M. Barns, D. A. Pelletier, and D. J. Lane, "16S ribosomal DNA amplification for phylogenetic study," Journal of Bacteriology, vol. 173, no. 2, pp. 697-703, 1991.

[41] S. F. Altschul, W. Gish, W. Miller, E. W. Myers, and D. J. Lipman, "Basic local alignment search tool," Journal of Molecular Biology, vol. 215, no. 3, pp. 403-410, 1990.

[42] M. A. Larkin, G. Blackshields, N. P. Brown et al., "Clustal W and Clustal X version 2.0," Bioinformatics, vol. 23, no. 21, pp. 29472948, 2007.

[43] M. Kimura, "A simple method for estimating evolutionary rates of base substitutions through comparative studies of nucleotide sequences," Journal of Molecular Evolution, vol. 16, no. 2, pp. 111120, 1980.

[44] K. Tamura, J. Dudley, M. Nei, and S. Kumar, "MEGA4: Molecular Evolutionary Genetics Analysis (MEGA) software version 4.0," Molecular Biology and Evolution, vol. 24, no. 8, pp. 15961599, 2007.

[45] D. M. Hillis and J. J. Bull, "An empirical test of bootstrapping as a method for assessing confidence in phylogenetic analysis," Systematic Biology, vol. 42, no. 2, pp. 182-192, 1993.

[46] J. J. Campanella, L. Bitincka, and J. Smalley, "MatGAT: an application that generates similarity/identity matrices using protein or DNA sequences," BMC Bioinformatics, vol. 4, article 29, 2003.

[47] J.-Y. Maillard, "Bacterial target sites for biocide action," Journal of Applied Microbiology Symposium Supplement, vol. 92, no. S1, pp. 16S-27S, 2002.

[48] X. Sheng, Y.-P. Ting, and S. O. Pehkonen, "Evaluation of an organic corrosion inhibitor on abiotic corrosion and microbiologically influenced corrosion of mild steel," Industrial and Engineering Chemistry Research, vol. 46, no. 22, pp. 7117-7125, 2007.

[49] V. Pruthi and S. S. Cameotra, "Rapid identification of biosurfactant-producing bacterial strains using a cell surface hydrophobicity technique," Biotechnology Techniques, vol. 11, no. 9, pp. 671-674, 1997.

[50] A. Harimawan, A. Rajasekar, and Y.-P. Ting, "Bacteria attachment to surfaces-AFM force spectroscopy and physicochemical analyses," Journal of Colloid and Interface Science, vol. 364, no. 1, pp. 213-218, 2011.

[51] V. Gallego, C. Sánchez-Porro, M. T. García, and A. Ventosa, "Massilia aurea sp. nov., isolated from drinking water," International Journal of Systematic and Evolutionary Microbiology, vol. 56, no. 10, pp. 2449-2453, 2006.
[52] B. La Scola, R. J. Birtles, M.-N. Mallet, and D. Raoult, "Massilia timonae gen. nov., sp. nov., isolated from blood of an immunocompromised patient with cerebellar lesions," Journal of Clinical Microbiology, vol. 36, no. 10, pp. 2847-2852, 1998.

[53] Y.-Q. Zhang, W.-J. Li, K.-Y. Zhang et al., "Massilia dura sp. nov., Massilia albidiflava sp. nov., Massilia plicata sp. nov. and Massilia lutea sp. nov., isolated from soils in China," International Journal of Systematic and Evolutionary Microbiology, vol. 56, no. 2, pp. 459-463, 2006.

[54] D. A. Moreno, J. R. Ibars, I. B. Beech, and C. C. Gaylarde, "Biofilm formation on mild steel coupons by Pseudomonas and Desulfovibrio," Biofouling, vol. 7, no. 2, pp. 129-139, 1993.

[55] R. Gubner and I. B. Beech, "The effect of extracellular polymeric substances on the attachment of Pseudomonas NCIMB 2021 to AISI 304 and 316 stainless steel," Biofouling, vol. 15, no. 1-3, pp. 25-36, 2000.

[56] A. Pedersen, S. Kjelleberg, and M. Hermansson, "A screening method for bacterial corrosion of metals," Journal of Microbiological Methods, vol. 8, no. 4, pp. 191-198, 1988.

[57] J. P. Busalmen, M. Vázquez, and S. R. De Sánchez, "New evidences on the catalase mechanism of microbial corrosion," Electrochimica Acta, vol. 47, no. 12, pp. 1857-1865, 2002.

[58] S. Maruthamuthu, P. Dhandapani, S. Ponmariappan, J.-H. Bae, N. Palaniswamy, and P. K. S. M. Rahman, "Impact of ammonia producing Bacillus sp. on corrosion of cupronickel alloy 90:10," Metals and Materials International, vol. 15, no. 3, pp. 409-419, 2009.

[59] H. Ashassi-Sorkhabi and S. A. Nabavi-Amri, "Polarization and impedance methods in corrosion inhibition study of carbon steel by amines in petroleum-water mixtures," Electrochimica Acta, vol. 47, no. 13-14, pp. 2239-2244, 2002.

[60] J. F. Batista, R. F. C. Pereira, J. M. Lopes, M. F. M. Carvalho, M. J. Feio, and M. A. M. Reis, "In situ corrosion control in industrial water systems," Biodegradation, vol. 11, no. 6, pp. 441-448, 2000.

[61] C. J. van Oss, "Hydrophobicity and hydrophilicity of biosurfaces," Current Opinion Colloid \& Interface Science, vol. 2, no. 5, pp. 503-512, 1997.

[62] L. Mei, H. C. Van Der Mei, Y. Ren, W. Norde, and H. J. Busscher, "Poisson analysis of streptococcal bond strengthening on stainless steel with and without a salivary conditioning film," Langmuir, vol. 25, no. 11, pp. 6227-6231, 2009.

[63] G. G. Geesey, M. W. Mittelman, T. Iwaoka, and P. R. Griffiths, "Role of bacterial exopolymers in the deterioration of metallic copper surfaces," Materials Performance, vol. 25, no. 2, pp. 3740, 1986. 

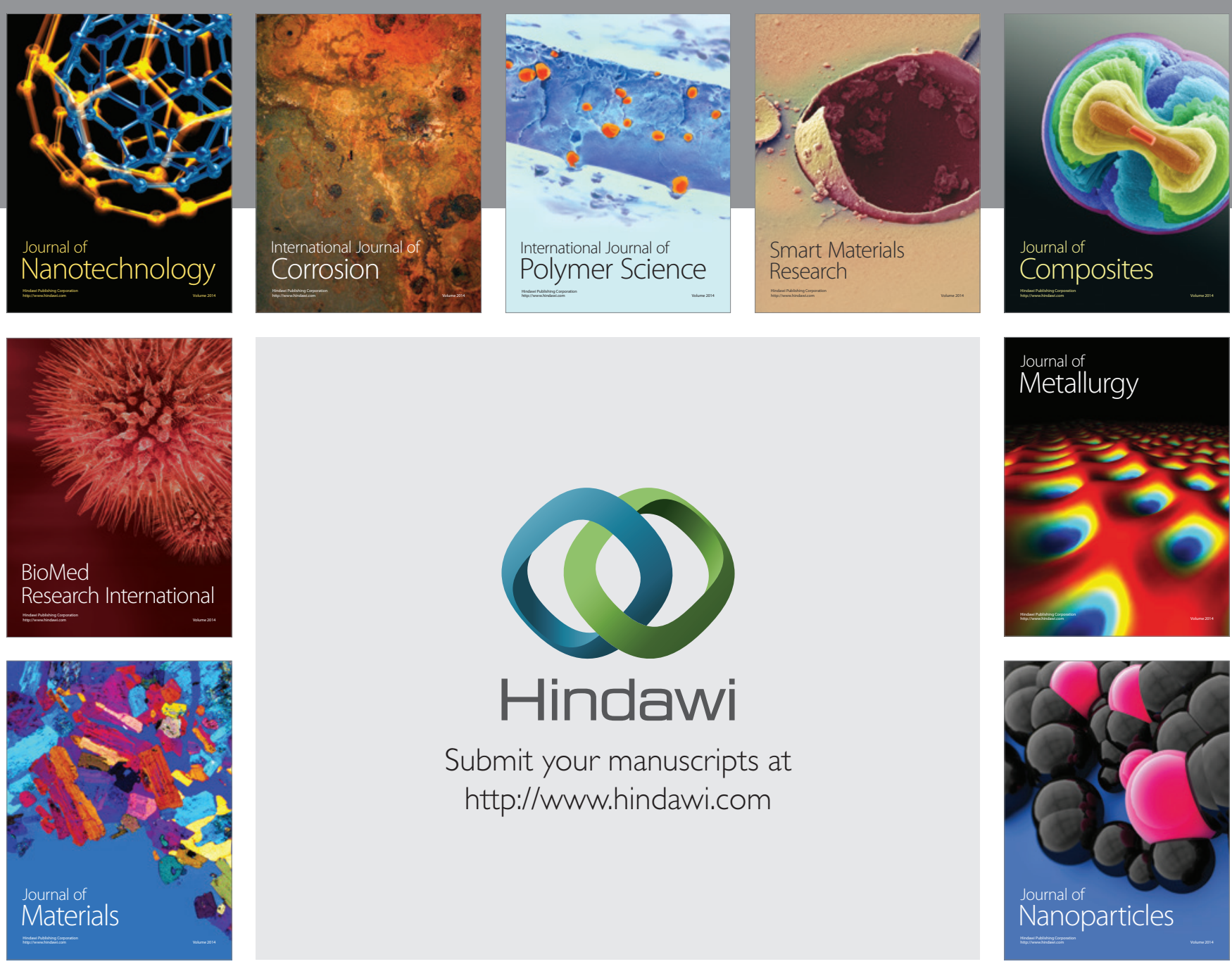

Submit your manuscripts at http://www.hindawi.com
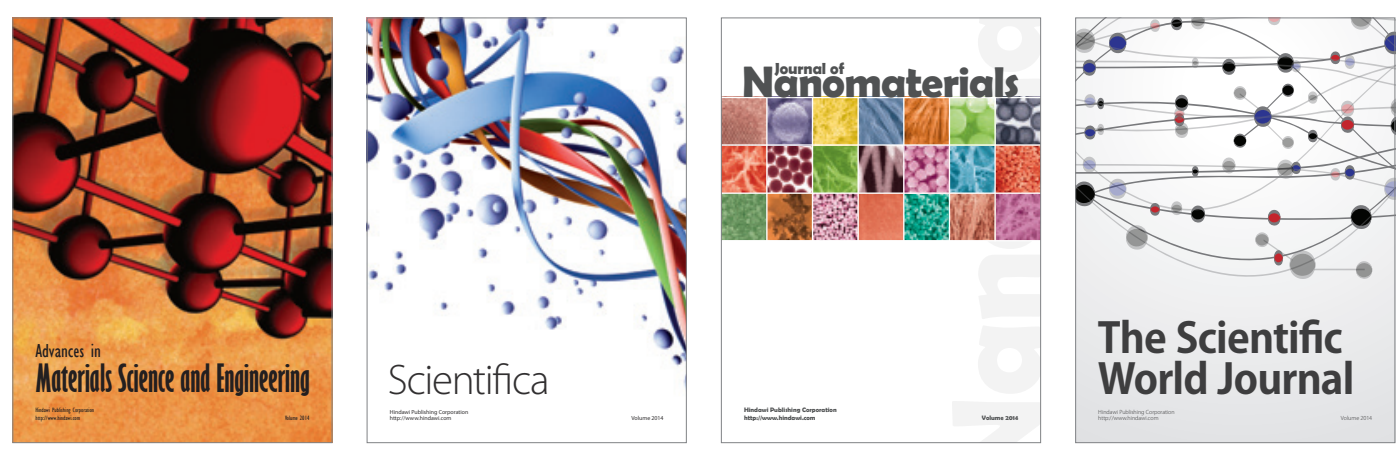

\section{The Scientific World Journal}
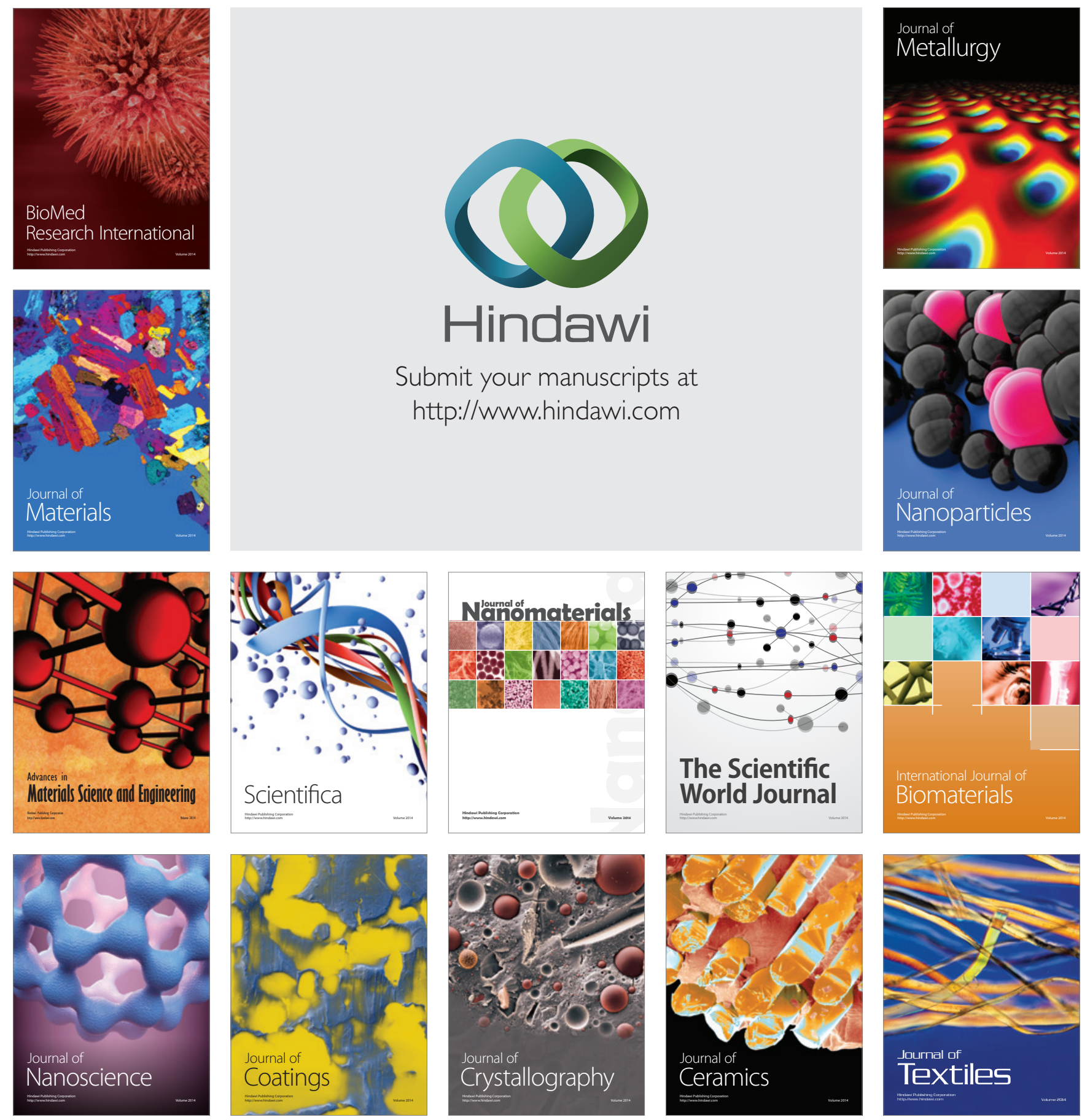